\title{
Economically Effective and Intelligently Responsive Home Energy Management System
}

\author{
MUHAMMAD IRFAN MUSHTAQ*, ASIF SIDDIQ*, MUHAMMAD OWAIS TARIQ*, \\ AKBAR ALI*, AND ANUM ZAHRA*
}

RECEIVED ON 30.04.2018 ACCEPTED ON 17.08.2018

\begin{abstract}
Energy management in home is one of the major issue now-a-days. There are different types of load like shiftable, non-shiftable, seasonal loads and auxiliary loads. In this research article, an energy management system is proposed for home which helps to schedule different loads on the basis of their types and price. It will help to minimize the cost of electricity by shifting load from peak time to off peak time. Emission will be minimized by charging penalty by adopting multi-objective optimization. Each source of energy has its own price of penalty with respect to time. Penalty is charged to minimize the use of sources like commercial supply and diesel generators which emits hazardous gases. In proposed model, user will get electricity from commercial supply, diesel generators and solar panels to provide continuous supply of electricity to fulfil the energy demand. The shiftable loads will be shifted from peak time to off peak time and higher price source to lower price source to minimize the overall price. In this research, we have proposed an EEIR (Economically Effective and Intelligently Responsive) HEMS (Home Energy Management System) by solving multi-objective optimization problem from BILP (Binary Integer Linear Programming) using branch and bound algorithm.
\end{abstract}

Key Words: Energy Management, Muliobjective Optimization, Emission, Branch and Bound Algorithm, Binary Integer Linear Programming.

\section{INTRODUCTION}

$\Gamma$

here is no energy management in traditional grid stations. The user has little information about the tariff, one of which is time of use tariff where there are some peak time slots in which price of energy is high and some slots are dedicated for low energy price. But user have little information about the peak timing and when load runs at that time, the electricity cost increases. We has proposed an energy management system to minimize the cost of energy and greenhouse gas emission as well. Solution to this problem is proposed as a system model for load management in building which introduces demand side management in smart grid. One of the proposed model [1] has three main modules; load balancing, admission control and demand response management. It enables interconnection between different components and integration of different energy sources with-in the system.

Authors E-Mail: (irfan.mushtaq258@gmail.com, irfan_258@yahoo.com)

* Pakistan Institute of Engineering and Technology, Multan, Pakistan.

This is an open access article published by Mehran University Research Journal of Engineering and Technology, Jamshoro under the CC by 4.0 International License. 
It also helps in system maintenance and up-gradation. Hence it is helpful for handling of autonomous energy management and consumption. An architecture was designed for load management in smart buildings and demand side management in smart grid [2]. Countering the problems of [2], an ICHEMS (Intelligent Cloud Home Energy Management System) was proposed in [3], which allows system loads to shift on priority basis at low price. Chen et. al. [4] showed that the appliances are connected through home area network, a communication based protocol was designed for load scheduling. A join access and scheduling technique was used to coordinate the appliances so that the demand values of power should be kept below the set value. The supplier gives the benefits to the user to use energy at off-peak time instead of peak time [5]. By using different demand side management techniques like peak clipping and valley filling, the loads are shifted from peak time to off-peak time to reduce the cost. The consumer can interact with the supplier to facilitate the load management at the supplier side [6]. The user can also schedule their load based on the price of energy by development of smart grid. The model by Zhao et. al. [7] has two parts, energy management system based on home area network and efficient scheduling. Wang et. al. [8] uses a vital methodology to integrate the vehicles for energy storage at off peak time to save energy and to sell this energy at peak time. Smart homes has the potential to improve the efficiency of the system. It also decreases the emission gases by using renewable energy sources. Another work made by Zipperer et. al. [9] gives the brief discussion for smart HEMS. Chang et. al. [10] proposed an architecture based on coordinated HEMS. The developed architecture helps the user to coordinate with their neighbor and schedule their appliances according to their supply. The user can manage his load depending upon the tariff of electricity by using demand side management in smart grid.
Each user finds an optimal time to start the appliances and operation time as well. Penalty is charged to overcome abrupt changes in the scheduling [11]. Han et. al. [12] proposed the HEMS in which power generation and power consumption both are considered. ZigBee network was used to monitor the power consumption of the appliances and lights. While PLC (Programmable Logic Controller) was used to monitor the total power generation from the solar panels. The home server collects the data of power generation and power consumption and analyzes the data and then schedules the appliances to minimize the energy cost. In Nguyen et. al. [13] an architecture was designed for energy scheduling with solar assisted heating, ventilation and air-conditioning system for household appliances. The benefit of the system was to generate the energy from solar at peak time and utilize the energy at off peak time. In this manner the price of energy was reduced. Optimal energy management is challenging issue associated with the smart micro-grids. The author has developed the multi-objective mixed integer nonlinear programming model for optimal energy used in smart homes [14]. Vivekananthan et. al. [15] has proposed another model for HEMS by scheduling, real time monitoring and real time control. By scheduling, user can meet their needs by using available resources. The home energy management helps to reduce the cost of electricity [16]. Althaher et. al. [17] gave a comprehensive home energy management system based on the controller. The controller controls the operation of appliances in response of dynamic pricing to reduce the electricity price. The load is shifted from higher price time to lower price time. A case study is done with different scenarios; the results show the effectiveness of the proposed system. Another study claims to have used MILP (Mixed Integer Linear Programming), CR (Continuous Relaxation), and FLC (Fuzzy Logic Controller) techniques for Home energy management [18]. Pan e. al. [19] uses 
HEMS for thermostatically controlled appliances. Decentralization techniques are also in use to monitor and control the load for domestic users, in which the primary balancing technique has a mechanism of receiving feedback from the users and updating the load schedule [20]. Some researchers have built outlet based sensors for measuring the actual loading of various devices [21]. Using these sensors, the HEMS schedules can become much more accurate. A group used Dijkstra algorithm for HEMS for simpler solutions [22]. Another attempt to understanding the need of HEMS at its best, compared load management without heating devices for regions where normally winter does not remain for long times [23]. Zhao et. al. [24] formulated HEMS of mixed supply types, in which AC and DC devices are considered as load. Another work demonstrated the demand side participation techniques for handling problems of a single and aggregated users combined by RDSA (Residential Demand-Side Aggregation) methods [25]. While focusing on uninterrupted power for user's comfort, monetarily focused studies have also been under taken to reduce the living expenses [26]. Along with constant priced units i.e. solar and wind, studies for solely dynamic pricing supplied have also been investigated [27]. Using such techniques for HEMS the users can not only maintain the comfort but also can attain this in lowest possible price.

Keeping in view the above mentioned objectives by the use of renewable energy sources and HEMS energy cost is decreased along with an add-on of minimized gas emission. In this research article economically effective and intelligently responsive HEMS is proposed to minimize the energy cost by scheduling different loads like shiftable loads on the basis of different available energy resources.
The paper consists of six sections. The section one is introduction of various techniques in use., section two is about proposed system model, the section three consists of methodology, section four is problem formulation, section five and section six are of simulation results and discussion and conclusion respectively. Section seven is about Acknowledgment.

\section{SYSTEM MODEL}

The proposed model for economically effective and intelligently responsive HEMS is shown in Fig 1. The proposed model consists of two parts: first is power generation and second is power consumption. Different sources available in home like commercial supply, diesel generator and solar cells in power generation section. All these power sources have different energy price at different time. The time of use tariff is generated based on the weighted sum of energy tariff plus penalty. Diesel has higher price as compared to the other two sources. The Solar has the least price. In this research we propose a model to minimize the cost and minimize the emission by scheduling different loads on the basis of price of different energy sources and by using penalty respectively using BBA (Branch and Bound Algorithm). The BBA is design paradigm for discrete and combinatorial optimization problem. It searches the solution from state space. The algorithm depends upon efficient estimation from lower bound and upper bound. If no upper bound and lower bounds are available, the algorithm degenerates to an exhaustive search.

\section{METHODOLOGY}

The Fig. 2 explains the methodology of proposed system, which starts by checking the availability of the power supplies. The penalty and actual unit cost is then calculated 
by the ratio of gas emission and power output. If more than one power supplies are available, then the decision is taken according to the price of the source and the low priced power supply is used to operate the appliances. Shiftable loads are then shifted from high priced area to low priced area of the load curve. The process of using shiftable loads at the time when unit price is low makes this HEMS much more effective.

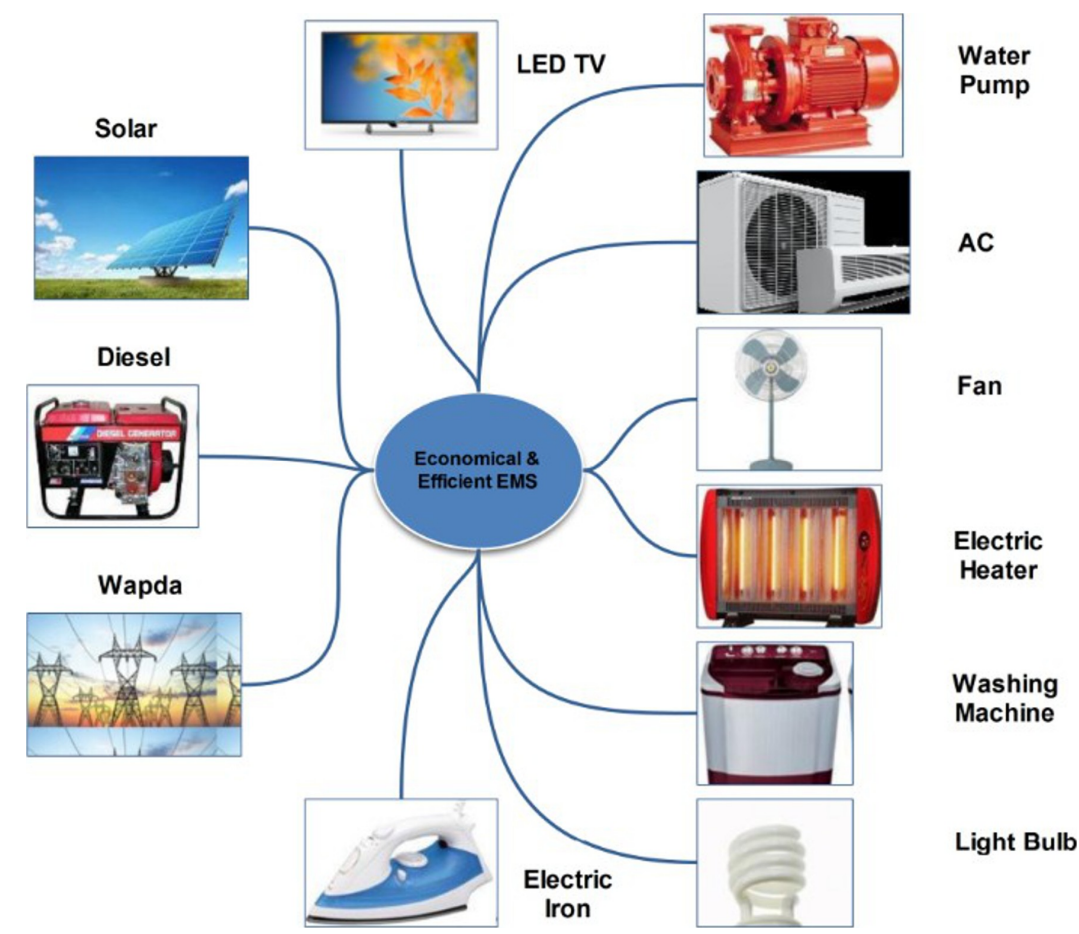

FIG. 1. ECONOMICALLY EFFECTIVE AND INTELLIGENTLY RESPONSIVE HOME ENERGY MANAGEMENT SYSTEM

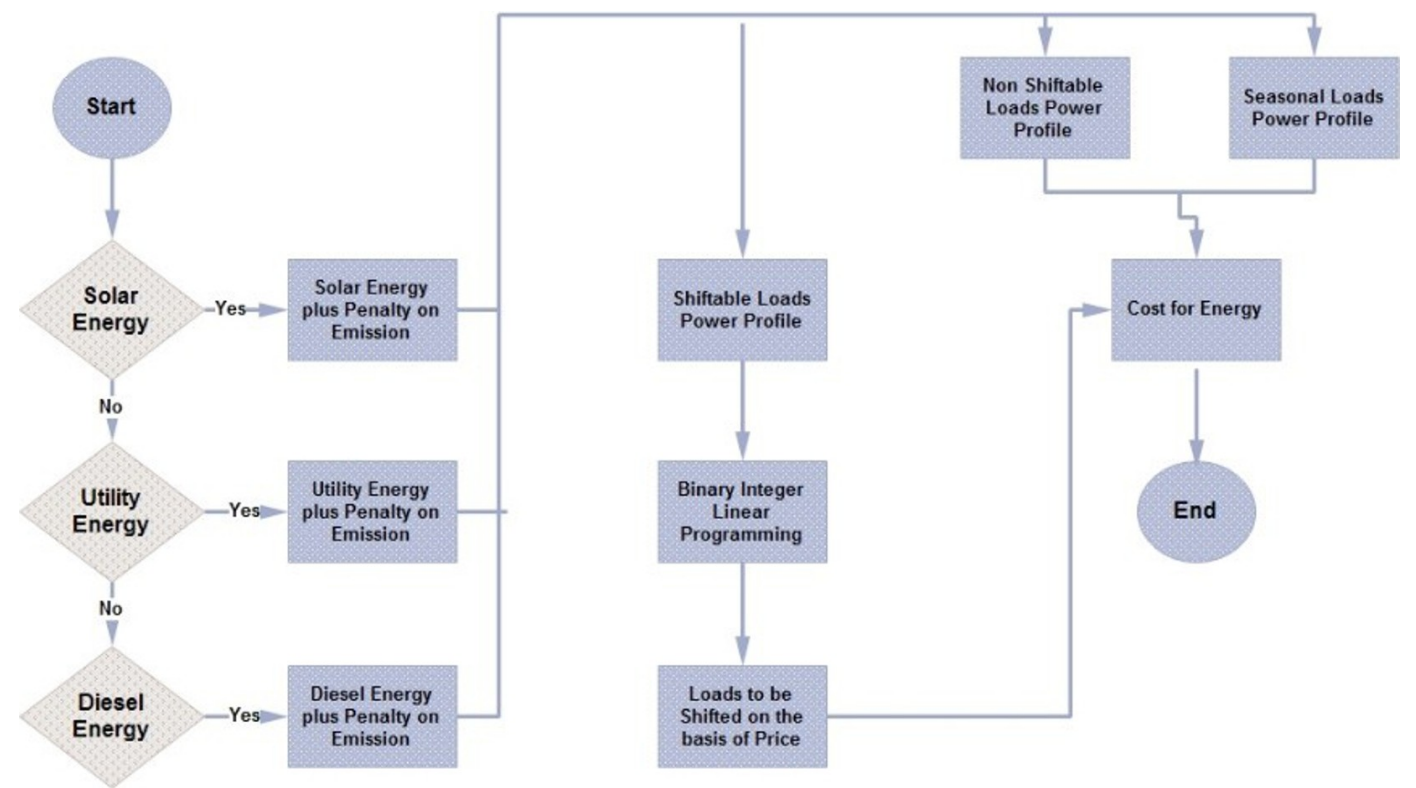

FIG. 2. FLOW CHART FOR METHODOLOGY OF PROPOSED MODEL 


\section{PROBLEM FORMULATION}

In this research we minimize the cost by shifting the loads from peak to off-peak time and reducing penalties. The problem formulation is given Equation (1):

$\min _{\mathrm{Y}}\left(\sum_{\mathrm{t} \in \mathrm{T}} \sum_{\mathrm{l} \in \mathrm{L}} \sum_{\mathrm{a} \in \mathrm{A}} \mathrm{W}_{1} \mathrm{Y}_{\mathrm{la}}^{\mathrm{t}} \mathrm{P}_{\mathrm{la}}^{\mathrm{t}} \mathrm{C}_{\mathrm{p}}^{\mathrm{T}}+\sum_{\mathrm{t} \in \mathrm{T}} \sum_{\mathrm{l} \in \mathrm{L}} \sum_{\mathrm{a} \in \mathrm{A}} \mathrm{W}_{2} \mathrm{Y}_{\mathrm{la}}^{\mathrm{t}} \mathrm{P}_{\mathrm{la}}^{\mathrm{t}} \mathrm{C}_{\mathrm{p}}^{\mathrm{T}}\right)$

In Equation (1), the binary integer variables, $\mathrm{Y}_{\mathrm{la}}{ }^{\mathrm{t}} \in\{0,1\}, \forall_{\mathrm{lt}}$ are the decision variables, an optimization problem is solved to formulate the home energy management system. The decision variable of load is 0 for OFF and 1 for $\mathrm{ON}$. The problem formulation of home energy management system is given in which $\mathrm{P}_{\text {la }}{ }^{\mathrm{t}}$ is the power profile of load, $\mathrm{C}_{\mathrm{P}}{ }^{\mathrm{t}}$ is the cost of energy. L represents the types of load, T represents the time, and A is total number of appliances.

$\mathrm{W}_{1}+\mathrm{W}_{2}=1$

In Equation (2) the $\mathrm{W}_{1}$ and $\mathrm{W}_{2}$ is equal to one. $\mathrm{W}_{1}$ is for minimization of cost and $\mathrm{W}_{2}$ is for emission minimization. If $\mathrm{W}_{1}=0.9$ then $\mathrm{W}_{2}=0.1$

$\mathrm{C}_{1}: \sum_{\mathrm{t}=1}^{\mathrm{T}} \mathrm{Y}_{\mathrm{la}}^{\mathrm{t}}=\mathrm{t}_{\mathrm{la}} \quad \forall, l t$

$\mathrm{C}_{2}: \sum_{\mathrm{t}=1}^{\mathrm{ts}+\text { tla }-1} \mathrm{Y}_{\mathrm{la}}^{\mathrm{t}}=\mathrm{t}_{\mathrm{la}} \forall, l t$

The Equations (3-4) represent constraint $\mathrm{C}_{1}$ and $\mathrm{C}_{2}$ are used for continuous time to finish the work. For continuous finish time, if $\mathrm{C}_{1}$ and $\mathrm{C}_{2}$ are equal to $\mathrm{t}$, then it will finish its work in given time otherwise it will not be able to finish the work in given time.

$\mathrm{C}_{3}: \sum_{1} \sum_{\mathrm{a}} \mathrm{Y}_{\mathrm{la}}^{\mathrm{t}} \mathrm{P}_{\mathrm{la}}^{\mathrm{t}}<\mathrm{P}_{\max } \forall \mathrm{t}$

In Equation (5) the constraints $\mathrm{C}_{3}$ is for peak clipping so that the maximum power consumption at a time should be minimized. In peak clipping the load is shifted from peak time to off peak time. This technique helps to reduce the power consumption at peak time.

$\mathrm{C}_{4}: \sum_{1} \sum_{\mathrm{a}} \mathrm{Y}_{\mathrm{la}}^{\mathrm{t}} \mathrm{P}_{\mathrm{la}}^{\mathrm{t}} \geq \mathrm{P}_{\min } \forall \mathrm{t}$

In Equation (6) $\mathrm{C}_{4}$ is for valley filling. In valley filling the user is appreciated to build or use the load where use of load is minimum.

$\mathrm{C}_{5}: \mathrm{Y}_{\mathrm{la}}^{\mathrm{t}} \in\{0,1\}$

In Equation (7) $\mathrm{C}_{5}$ is for decision variable. Value of $\mathrm{C}_{5}$ will be either zero or one. If $\mathrm{C}_{5}$ is one, then the appliance ' $\mathrm{a}$ ' at any time ' $\mathrm{t}$ ' will be switched $\mathrm{ON}$. If $\mathrm{C}_{5}$ is zero, then the appliances ' $a$ ' at any time ' $t$ ' will be switched OFF. The main objective of the proposed model is to minimize the cost of the energy used and the emission of carbon based hazardous gases. In this problem weighted sum is used to minimize the cost and emission. The $\mathrm{W}_{1}$ is used to minimize the cost of energy used and $\mathrm{W}_{2}$ is used to minimize the carbon emission gases.

\section{SIMULATION RESULTS AND DISCUSSION}

The simulation is performed on MATLAB version $\mathrm{R} 2013 \mathrm{a}$ running on Intel dual core i3 system having 4GB of RAM and 500GB of ROM. The time span is given as $24 \mathrm{hr}$ in different available energy tariff and penalty using tariff. The cost is given in 500 price steps in final results. In this research the main emphasis is on two entities, one is to minimize the $\operatorname{cost}\left(\mathrm{W}_{1}\right)$ and second is to minimize the emission $\left(\mathrm{W}_{2}\right)$. The sum of $\mathrm{W}_{1}$ and $\mathrm{W}_{2}$ is always equal to one. If the value of $\mathrm{W}_{1}$ is equal to 0.2 then the value of $\mathrm{W}_{2}$ will be equal to 0.8 , if the value of $\mathrm{W}_{1}$ is equal to 0.9 then the value of $\mathrm{W}_{2}$ will automatically be equal to 0.1 . We have different energy resources like utility, diesel generators and solar cells, so as their values of $\mathrm{W}_{1}$ and $\mathrm{W}_{2}$. These values can be remodeled 
for the application in use. There are also different type of loads having different no. of appliances.

Table 1 describes different types of loads with different type of appliances. Each type of load has different type of appliances like non-shiftable loads are considered as fan and refrigerator. The shiftable loads are consisted of water pump, washing machine, dryer, and TV. The seasonal loads are $\mathrm{AC}$ and heater. The lights are considered as auxiliary load. The shiftable loads are shifted from peak time to offpeak time so that cost can be minimized

In Fig. 3 the $\mathrm{U}_{\text {Tou }}$ is the utility energy source, the $\mathrm{D}_{\text {Tou }}$ diesel energy source and $\mathrm{S}_{\text {Tou }}$ is the energy generated by the solar cells. All these energy resources have different energy price at different time. The price of tariff and penalty is given in PKR (Pakistani Rupee). Penalty is also charged for using the tariff.

Table 2 shows the price of electricity generated from solar cells. The price of electricity is given is different at different time slots.

Table 3 shows the price of electricity provided by electricity
Supplier Company. The price of electricity is given different at different time slots.

Table 4 describes the price of electricity generated from Diesel generators. The price of electricity is given is different at different time slots.

Fig. 4 shows the tariff of penalty for using the different energy tariff like solar tariff, diesel tariff and utility tariff. Each tariff has its own price of penalty that is charged to use the tariff. We have used weighted sum $\mathrm{W}_{1}+\mathrm{W}_{2}=1$. $\mathrm{W}_{1}$ is for

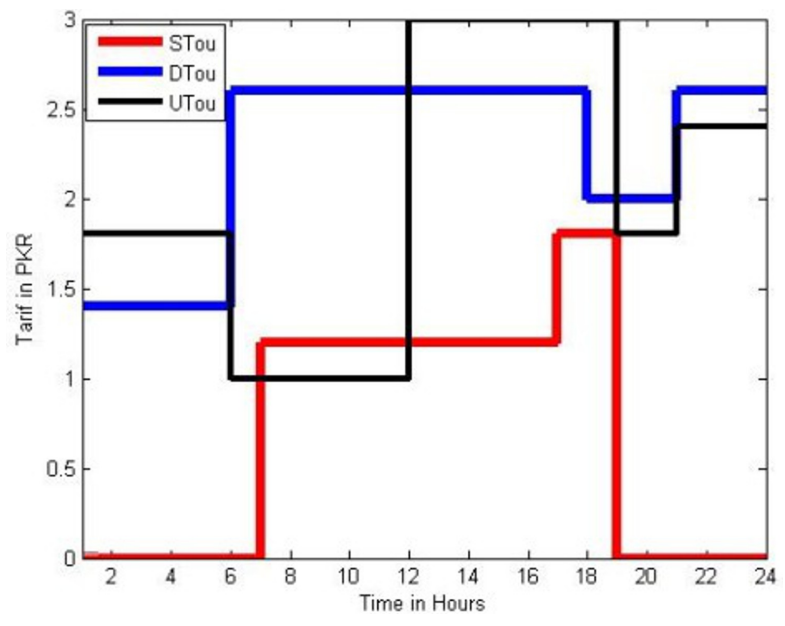

FIG. 3. DIFFERENT AVAILABLE ENERGY TARIFF

TABLE 1. DIFFERENT TYPES APPLIANCES OF DIFFERENT LOAD TYPES

\begin{tabular}{|c|c|c|c|c|c|c|c|c|}
\hline \multirow[b]{2}{*}{ No. } & \multicolumn{2}{|c|}{ Shiftable Load } & \multicolumn{2}{|c|}{ Non-Shiftable Load } & \multicolumn{2}{|c|}{ Seasonal Load } & \multicolumn{2}{|c|}{ Auxiliary Load } \\
\hline & $\begin{array}{c}\text { Name of } \\
\text { Appliances }\end{array}$ & $\begin{array}{c}\text { Power } \\
\text { Consumption } \\
(\mathrm{KW})\end{array}$ & $\begin{array}{c}\text { Name of } \\
\text { Appliances }\end{array}$ & $\begin{array}{c}\text { Power } \\
\text { Consumption } \\
(\mathrm{KW})\end{array}$ & $\begin{array}{c}\text { Name of } \\
\text { Appliances }\end{array}$ & $\begin{array}{c}\text { Power } \\
\text { Consumption } \\
(\mathrm{KW})\end{array}$ & $\begin{array}{c}\text { Name of } \\
\text { Appliances }\end{array}$ & $\begin{array}{c}\text { Power } \\
\text { Consumption } \\
(\mathrm{KW})\end{array}$ \\
\hline 1. & Water Pump & 0.7 & Fan & 0.5 & Air-Conditioner & 2.8 & Lights & 0.2 \\
\hline 2. & Washing Machine & 0.65 & Refrigerator & 0.170 & Heater & 1 & - & - \\
\hline 3. & Television & 0.5 & - & - & - & - & - & - \\
\hline 5. & Dryer & 0.70 & - & - & - & - & - & - \\
\hline
\end{tabular}

TABLE 2. SOLAR PRICE (PKR)

\begin{tabular}{|c|c|c|c|c|}
\hline Source & $0-7$ (Hours) & $7-17$ (Hours) & $17-19$ (Hours) & $19-24$ (Hours) \\
\hline Solar Price & Not Available & 1.3 & 1.8 & Not Available \\
\hline
\end{tabular}

TABLE 3. UTILITY PRICE (PKR)

\begin{tabular}{|c|c|c|c|c|c|}
\hline Source & $0-6$ (Hours) & $6-12$ (Hours) & $12-19$ (Hours) & $19-21$ (Hours) & $21-24$ (Hours) \\
\hline Utility Price & 1.8 & 1.0 & 3.0 & 1.8 & 2.4 \\
\hline
\end{tabular}

Mehran University Research Journal of Engineering \& Technology, Volume 38, No. 3, July, 2019 [p-ISSN: 0254-7821, e-ISSN: 2413-7219] 
price and $\mathrm{W}_{2}$ is for emission. If $\mathrm{W}_{1}=0.9$ then it means the weightage for price minimization is 0.9 and for emission is 0.1 . The factor which has more value will be minimized more than other factor. If we set value of $\mathrm{W}=0.8$ then the emission will be further minimized more but price of electricity bill will not minimum. Emission is also most important factor, because emission gases are harmful to the environment. It can be analyzed when value of $\mathrm{W}_{1}=0.2$ the value of $\mathrm{W}_{2}$ will be equal to 0.8 , so price will be high but emission will be minimized. The penalty is charged due to emission gases emitted during generation of electricity.

Fig. 5 shows the time of use tariff generated from available resources of energy on basis of low price and availability. Time of use tariff has different price of energy at different time. It can be seen that in time slot 0-300 the price is maximum, the price in time slot 900-1100 is also high. The price during time slot 300-900 is less. But cost is lowest during time slot of 1100-1440.

Fig. 6 represents the final result achieved. The maximum load is shifted from higher price to lower price as shown in time of use tariff. In time of use tariff, the price is low at time slots 1100-1400-time slot. We can see that the cost is minimized in Fig. 6 when $\mathrm{W}_{1}=0.9$ and $\mathrm{W}_{2}=0.1$, the main consideration is cost so cost is reduced to PKR 3400/- instead of PKR 3800/-. According to Fig. 6 the cost is minimized up to $10.25 \%$ in optimum case.

Fig. 7 shows that when $\mathrm{W}_{1}=0.2$ and $\mathrm{W}_{2}=0.8$, then emission is main factor to minimize and cost has less weitage. It can be seen that cost goes high from PKR 2400/- to PKR 3400/because in this case emission was main factor and penalty is charged due to which cost goes high but emission is minimized. By analyzing the both results shown in Figs. 6-7 the maximum cost is minimized in Fig. 6 because the emission factor is neglected. In this way cost and emission are minimized by using the proposed model by solving BILP using BBA. In Fig. 7 the emission is minimized but cost goes high because of the higher weightage of emission. The proposed economically efficient and intelligently responsive HEMS is also applicable for industries to minimize the cost and emission.

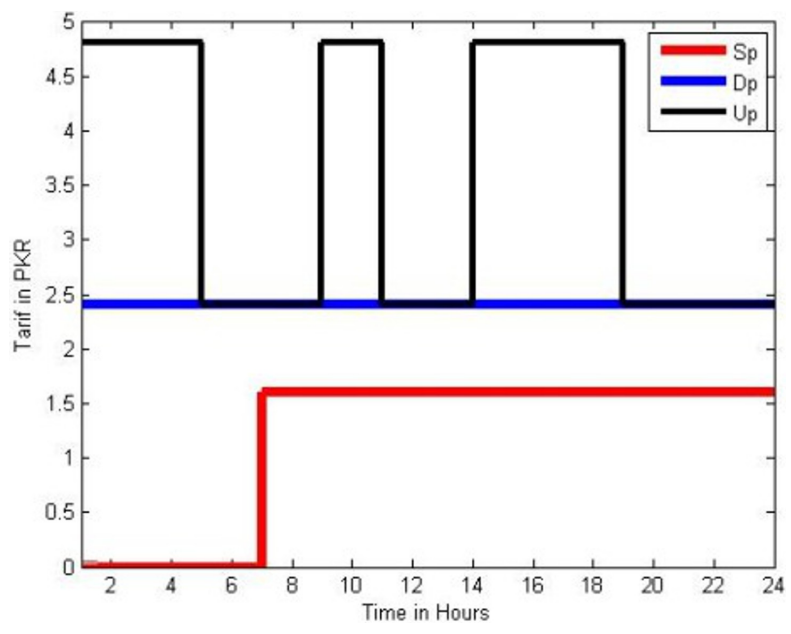

FIG. 4. PENALTY FOR USING TARIFF

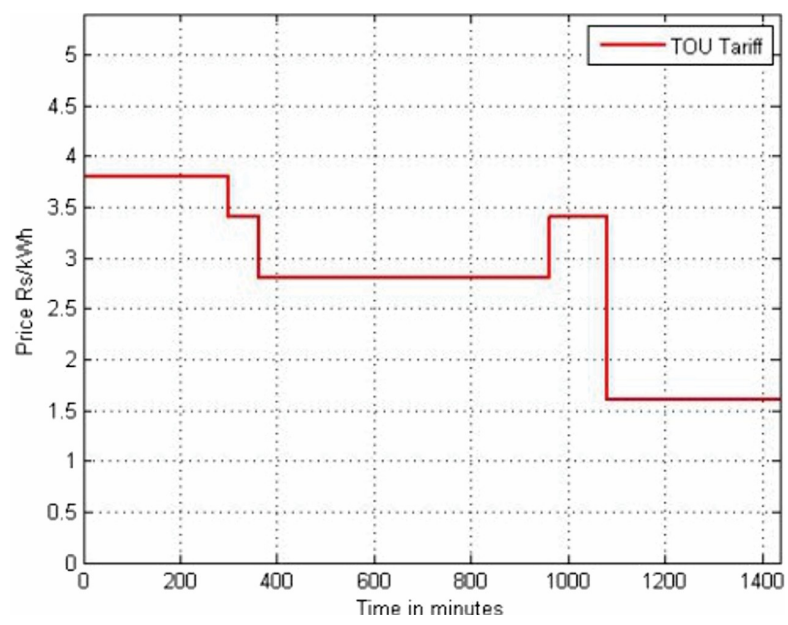

FIG. 5. TIME OF USE TARIFF

TABLE 4. DIESEL PRICE (PKR)

\begin{tabular}{|c|c|c|c|c|}
\hline Source & $0-6$ (Hours) & $6-18$ (Hours) & $18-21$ (Hours) & $21-24$ (Hours) \\
\hline Diesel Price & 1.8 & 2.6 & 2 & 2.6 \\
\hline
\end{tabular}

Mehran University Research Journal of Engineering \& Technology, Volume 38, No. 3, July, 2019 [p-ISSN: 0254-7821, e-ISSN: 2413-7219] 


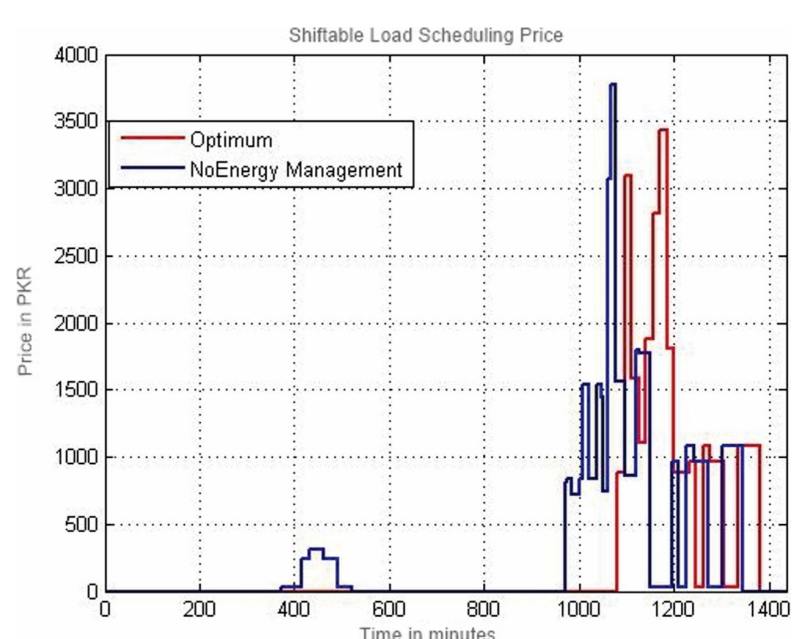

FIG. 6. OPTIMAL ENERGY MANAGEMENT WHEN $W_{l}=0.9$

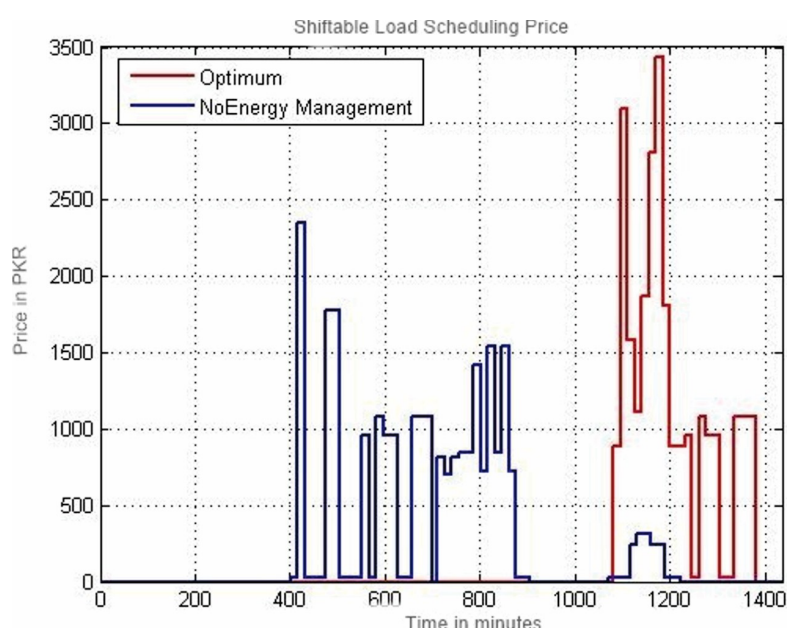

FIG. 7. OPTIMAL ENERGY MANAGEMENT WHEN $W_{1}=0.2$
Table 5 shows the comparison of different energy management systems with our proposed energy management system. The cost saved by different energy management system is $1.8-8.1 \%$. The cost saved by our proposed energy management system is $10.25 \%$. EE\&IR HEMS is also applicable for small as well as large industries.

\section{CONCLUSIONS}

Economically effective and intelligently responsive HEMS is proposed to minimize the cost and emission. By using proposed system, the cost is minimized by shifting shiftable loads to $10.25 \%$. The gas emission is reduced by shifting the load to minimum emission power supplies, hence increasing the cost. In future the proposed model can also be used in small and large industries.

\section{ACKNOWLEDGEMENT}

The authors are grateful to Pakistan Institute of Engineering \& Technology, Multan, Pakistan, for providing conducive environment for completion of this research work.

TABLE 5. COMPARISON OF ENERGY MANAGEMENT

\begin{tabular}{|c|c|c|c|}
\hline References & Energy Management Area & Technique & Energy/Price Saved \\
\hline \multirow{2}{*}{ Byun et. al. [3] } & \multirow{2}{*}{$\begin{array}{l}\text { Cloud based energy management } \\
\text { system }\end{array}$} & Standalone type priority based scheduling & $6.5 \%$ \\
\hline & & Server based type priority based scheduling & $8.1 \%$ \\
\hline \multirow{2}{*}{ Chen et. al. [4] } & \multirow{2}{*}{$\begin{array}{c}\text { Appliance scheduling for energy } \\
\text { management system }\end{array}$} & Without Wind & $7.3 \%$ \\
\hline & & With wind & $6 \%$ \\
\hline Ozturk et. al. [5] & Intelligent home energy management system & Mix integer non-linear programming & $7 \%$ \\
\hline \multirow{2}{*}{ Vivekananthan et. al. [15] } & \multirow{2}{*}{$\begin{array}{l}\text { Real time price based home energy } \\
\text { management scheduler }\end{array}$} & Energy Saved annually & $791.2 \mathrm{KWh}$ \\
\hline & & Cost Saved annually & 187.03 \\
\hline Safdarian et. al. [20] & Load management in smart grid & Decentralized Framework & $1.8 \%$ \\
\hline Li and Jiang [27] & Cost Efficient home energy management system & Cost Saved & 1.45 US\$/day \\
\hline Proposed Model & EE\&IR home energy management system & Cost Saved & $10.25 \%$ \\
\hline
\end{tabular}

Mehran University Research Journal of Engineering \& Technology, Volume 38, No. 3, July, 2019 [p-ISSN: 0254-7821, e-ISSN: 2413-7219] 


\section{REFERENCES}

Qela, B., and Mouftah, H.T., "Observe, Learn, and Adapt (OLA): An Algorithm for Energy Management in Smart Homes Using Wireless Sensors and Artificial Intelligence", IEEE Transactions on Smart Grid, Volume 3, No. 4, pp. 2262-2272, 2012.

Costanzo, G.T., Zhu, G., Anjos, M.F., and Savard, G., "A System Architecture for Autonomous Demand Side Load Management in Smart Buildings", IEEE Transactions on Smart Grid, Volume 3, No. 4, pp. 2157-2165, 2012.

Byun, J., Hong, I., and Park, S., "Intelligent Cloud Home Energy Management System Using Household Apageliance Priority Based Scheduling Based on Prediction of Renewable Energy Capability", IEEE Transactions on Consumer Electronics, Volume 58, No. 4, 2012.

Chen, C., Nagananda, K., Xiong, G., Kishore, S., and Snyder, L.V., "A Communication-Based Appliance Scheduling Scheme for Consumer-Premise Energy Management Systems", IEEE Transactions on Smart Grid, Volume 4, No. 1, pp. 56-65, 2013.

Ozturk, Y., Senthilkumar, D., Kumar, S., and Lee, G., "An Intelligent Home Energy Management System to Improve Demand Response", IEEE Transactions on Smart Grid, Volume 4, No. 2, pp. 694-701, 2013.

Hu, Q., and Li, F., "Hardware Design of Smart Home Energy Management System Dynamic Price Response”, IEEE Transactions on Smart Grid, Volume 4, No. 4, pp. 1878-1887, 2013.

Zhao, Z., Lee, W.C., Shin, Y., and Song, K.B., “An Optimal Power Scheduling Method for Demand Response in Home Energy Management System", IEEE Transactions on Smart Grid, Volume 4, No. 3, pp. 1391-1400, 2013.

[8] Wang, Z., Gu, C., Li, F., Bale, P., and Sun, H., "Active Demand Response Using Shared Energy Storage for Household Energy Management”, IEEE Transactions on Smart Grid, Volume 4, No. 4, pp. 1888-1897, 2013.
[9] Zipperer, A., Aloise-Young, P.A., Suryanarayanan, S., Roche, R., Earle, L., Christensen, D., Bauleo, P., and Zimmerle, D., "Electric Energy Management in the Smart Home: Perspectives on Enabling Technologies and Consumer Behavior", Proceedings of the IEEE, Volume 101, No. 11, pp. 2397-2408, 2013.

[10] Chang, T.H., Alizadeh, M., and Scaglione, A., "RealTime Power Balancing Via Decentralized Coordinated Home Energy Scheduling", IEEE Transactions on Smart Grid, Volume 4, No. 3, pp. 1490- 1504, 2013.

[11] Chavali, P., Yang, P., and Nehorai, A., "A Distributed Algorithm of Appliance Scheduling for Home Energy Management System", IEEE Transactions on Smart Grid, Volume 5, No. 1, pp. 282-290, 2014.

[12] Han, J., Choi, C.S., Park, W.K., Lee, I., and Kim, S.H., "Smart Home Energy Management System Including Renewable Energy Based on ZigBee and PLC", IEEE Transactions on Consumer Electronics, Volume 60, No. 2, pp. 198-202, 2014.

[13] Nguyen, H.T., Nguyen, D.T., and Le, L.B., "Energy Management for Households With Solar Assisted Thermal Load Considering Renewable Energy and Price Uncertainty", IEEE Transactions on Smart Grid, Volume6, No. 1, pp. 301-314, 2015.

[14] Anvari-Moghaddam, A., Monsef, H., and Rahimi-Kian, A., "Optimal Smart Home Energy Management Considering Energy Saving and a Comfortable Lifestyle", IEEE Transactions on Smart Grid, Volume 6, No. 1, pp. 324-332, 2015.

[15] Vivekananthan, C., Mishra, Y., and Li, F., "Real-Time Price Based Home Energy Management Scheduler", IEEE Transactions on Power Systems, Volume 30, No. 4, pp. 2149-2159, 2015.

[16] Lin, Y.H., and Tsai, M.S., "An Advanced Home Energy Management System Facilitated by Nonintrusive Load Monitoring with Automated Multiobjective Power Scheduling", IEEE Transactions on Smart Grid, Volume 6, No. 4, pp. 1839-1851, 2015. 
[17] Althaher, S., Mancarella, P., and Mutale, J., “Automated Demand Response from Home Energy Management System Under Dynamic Pricing and Power and Comfort Constraints", IEEE Transactions on Smart Grid, Volume 6, No. 4, pp. 1874-1883, 2015.

[18]

Wu, Z., Zhang, X.P., Brandt, J., Zhou, S.Y., and JiaNing, L., "Three Control Approaches for Optimized Energy Flow with Home Energy Management System”, IEEE Power and Energy Technology Systems Journal, Volume 2, No. 1, pp. 21-31, 2015.

[19] Pan, Z., Guo, Q., and Sun, H., "Impacts of Optimization Interval on Home Energy Scheduling for Thermostatically Controlled Appliances", CSEE Journal of Power and Energy Systems, Volume 1, No. 2, pp. 90-100, 2015.

[20] Safdarian, A., Fotuhi-Firuzabad, M., and Lehtonen, M., "Optimal Residential Load Management in Smart Grids: A Decentralized Framework", IEEE Transactions on Smart Grid, Volume 7, No. 4, pp. 1836-1845, 2016.

[21] Tsunoda, Y., Tsuchiya, C., Segawa, Y., Sawaya, H., Hasegawa, M., Ishigaki, S., and Ishibashi, K., “A SmallSize Energy-Harvesting Electric Power Sensor for Implementing Existing Electrical Appliances into HEMS", IEEE Sensors Journal, Volume 16, No. 2, pp. 457-463, 2016.
[22] Basit, A., Sidhu, G.A.S., Mahmood, A., and Gao, F., "Efficient and Autonomous Energy Management Techniques for the Future Smart Homes", IEEE Transactions on Smart Grid, Volume 8, No. 2, pp. 917-926, 2017.

[23] Sun, H., "Foreword for the Special Section on Smart Grid Energy Management", CSEE Journal of Power and Energy Systems, Volume 1, No. 4, pp. 1-2, 2015.

[24] Zhao, C., Dong, S., Li, F., and Song, Y., "Optimal Home Energy Management System with Mixed Types of Loads", CSEE Journal of Power and Energy Systems, Volume 1, No. 4, pp. 29-37, 2015.

[25] Chapman, A.C., Verbic, G., and Hill, D.J., "Algorithmic and Strategic Aspects to Integrating Demand-Side Aggregation and Energy Management Methods", IEEE Transactions on Smart Grid, Volume 7, No. 6, pp. $2748-2760,2016$

[26] Flores, J.T., Celeste, W.C., Coura, D.J.C., das Dores Rissino, S., Rocha, H.R.O., and Moraes, R.E.N., "Demand Planning in Smart Homes", IEEE Latin America Transactions, Volume 14, No. 7, pp. 3247-3255, 2016.

[27] Li, M., and Jiang, C.W., "QoE-Aware and Cost-Efficient Home Energy Management Under Dynamic Electricity Prices",IEEE $9^{\text {th }}$ International Conference on Ubiquitous and Future Networks, pp. 498-501, 2017. 